\title{
Immunohistochemical Localization of Ghrelin and IGF-I (Insulin-Like Growth Factor-I) in the Liver and Kidney Tissues of Melatonin-Treated Rats
}

\author{
Saltan $\mathrm{SK}^{1}$ and Aslan $\mathrm{S}^{*_{2}}$ \\ ${ }^{1}$ Health Research and Practice Hospital, Kafkas University, Kars, TURKEY \\ ${ }^{2}$ Department of Histology and Embryology, Faculty of Veterinary Medicine, Kafkas University, Kars, TURKEY
}

*Corresponding author: Aslan S, Department of Histology and Embryology, Faculty of Veterinary Medicine, Kafkas University, TR-36100, Kars, Turkey, E-mail: sahinaslan0644@hotmail.com

Citation: Saltan SK, Aslan S (2017) Immunohistochemical Localization of Ghrelin and IGF-I (Insulin-Like Growth Factor-I) in the Liver and Kidney Tissues of Melatonin-Treated Rats. J Vet Sci Ani Husb 5(4): 401. doi: $10.15744 / 2348-9790.5 .401$

Received Date: July 26, 2017 Accepted Date: December 27, 2017 Published Date: December 29, 2017

\begin{abstract}
This study was conducted to investigate the immunohistochemical localization of ghrelin and IGF-I in the liver and kidney tissues in melatonin-treated rats. Rats were divided into three groups as a control, a sham and a treatment groups. While the treatment group received melatonin (10 mg/kg i.p.) for 3 weeks, only ethanol and saline solution were administered to the sham group. The control group received nothing.

Melatonin administration was observed to reduce body weight and cause an increase in the number of binucleated hepatocytes in the liver.

It was concluded that melatonin administration increased IGF-I immunoreactivity in the liver and in thekidney. Melatonin administration was determined to lead to a decrease in ghrelin immunoreactivity in the kidney, but no changes in ghrelin immunoreactivity in the liver. Melatonin caused an increase in IGF-I immunoreactivity in the liver and kidney via suppression of ghrelin release.

This study will lead to a greater understanding of the relationship between melatonin, IGF-I and ghrelin.

Keywords: Ghrelin; IGF-I; Immunohistochemistry; Kidney; Liver; Melatonin
\end{abstract}

\section{Introduction}

Melatonin is synthesized and secreted by epiphysis (pineal gland) during the night. It regulates a lot of biological function such as biological rhythm, reproduction and immunity. Furthermore, it is a powerful antioxidant [1-3].

Recently, it has been shown that melatonin is associated with oxidative stress in terms of both as a free radical scavenger and an antioxidant. The high lipophilicity of melatonin is the most important advantage as a free radical scavenger [4-7]. One of melatonin features is to be soluble both in water and oil so it can show its antioxidant effect in wide range of organism. There are no known any morphophysiological barriers for melatonin, which can easily crosses the blood-brain barrier and placenta, therefore, it reaches all intracellular components easily and, effectively protects cell membrane, organelles and nucleus against damage from free radicals [8]. The ability of melatonin to reach the cell nucleus shows its superiority over other antioxidant in protecting DNA against oxidative damage [8]. More importantly, in contrast to other antioxidants melatonin does not have toxic effects, even at very high doses (300 mg / day) and long-term use (5 years) [9].

Ghrelin is known as the hunger hormone, and it is mainly expressed in stomach in all vertebrate [10]. Apart from stomach, it was detected in hypothalamus, pituitary, liver, pancreas, testis, ovary and placenta in both humans and rodents [11,12]. Significant amounts of ghrelin have also been detected in kidney. It has been shown that pre-proghrelin gene is expressed in rat kidney [13].

Effects of ghrelin on growth hormone secretion, food intake, carbohydrate metabolism, gastrointestinal system, physiology and reproductive system were reported [14-18]. In addition to these effects, ghrelin has an antioxidant effect. This antioxidant property prevents oxidative stress and apoptosis in tissues [19,20]. Ghrelin also protects liver and pancreatic tissues against oxidative damage [21].

Ghrelin have effects on growth hormone and to increase its secretion in both in vitro and in vivo [22-24]. Ghrelin reduces somatostatin release but increases Growth Hormone Releasing Hormone (GHRH) release [25]. 
Ghrelin has anti-apoptotic effects and, reduces the toxic effects of cytotoxic agents [19,26]. Chung et al. [19] have shown that ghrelin inhibits apoptotic pathway by suppressing the secretion of cytochrome $\mathrm{c}$ and caspase 3 during ischemia, in this way ghrelin protects brain from damage.

Insulin-like growth factors (IGFs) are short peptides that generally act locally and whose primary amino acid sequences resemble each other [27-29]. IGF-I is a kind of growth factor which is a member of IGF family and, contains 70 amino acids [27,28].

Large amounts of IGFs in blood circulation are synthesized by the liver [30]. It is thought that the major IGFs synthesis cells are perisinusoidal cells but IGFs get theirs the final shape in hepatocytes. According to another opinion, IGFs syntesis occur in both cells and it passes the blood circulation through hepatic sinuses. IGFs are also synthesized in many tissues apart from the liver such as fetal lung, kidney, brain, intestine, heart and fibroblast cells [31,32].

When IGFs in circulation have endocrine effects, locally produced IGFs have autocrine or paracrine effects [33]. IGF-I affects almost all cells in the tissues such as muscle, cartilage, bone, kidneys, lungs, skin and nerves. In addition to insulin like effects, IGF-I also stimulates cell growth and proliferation [34,35]. The hydroxyl radical from the free radicals causes cirrhosis in the liver; it also causes lipid peroxidation in the cell membrane and DNA damage. IGF-I has a therapeutic effect against the harmful effects of the free radical as an antioxidant [36]. At the same time, IGFs have a synergistic effect with Thyroid Stimulating Hormone (TSH) on the thyroid follicular cell proliferation. IGFs also stimulate the synthesis of DNA, RNA, protein, collagen and proteoglycan in cartilage tissue and, play an important role in the process of wound healing [33].

IGF-I level decreases during growing up, are affected by feeding independently of growth hormone and, also increases during intrauterine growth retardation $[37,38]$.

IGFBP-I increases before meals like ghrelin, whereas the insulin hormone decreases before meals like IGF-I. IGF-I is affected by this situation and decreases at the tissue levels.

Decreased ghrelin levels with age, especially with puberty, leads to increase in IGF-I levels, and it accelerates growth [39]. All these findings suggest that ghrelin is not a direct hormone that situmulates growth, but it has an effect secondarily on growth via IGF-I, which accelerates growth especially in puberty [39]. In addition, Takeda et al. [20] showed that ghrelin promotes renal function through IGF-I in acute renal failure, which is the result of ischemia.

Melatonin causes phosphorylation of the insulin-like growth factor receptor (IGF-R) and insulin receptor tyrosine by mediating the activation of key signalling pathways necessary for the survival and growth of the cell. In addition, there are many studies showing the effects of melatonin on IGF-I which is an important growth factor [40-42]. Melatonin regulates the growth and differentiation of pancreatic islets by activating IGF-I and insulin receptor signalling pathways [41]. In a study on muscle atrophy of infertile rats showed that IGF-I increased and muscle atrophy was prevented in the melatonin and testosterone group, whereas muscle degeneration was observed in the group without melatonin and testosterone [43]. Studies on the effects of melatonin on ghrelin have also been conducted [44,45]. Canpolat et al. [23] investigated the immunohistochemical distributions of ghrelin in arcuate nuclei and ghrelin serum levels in melatonin-treated and pinealectomized rats. As a result of this study, it was thought that melatonin may have an inhibitory effect on the onset of puberty by causing both increase in ghrelin synthesis and decrease in leptin production [44]. It has also been reported that melatonin reduces ghrelin levels in blood circulation by suppressing ghrelin production and, for this reason; it has a role about regulating of ghrelin synthesis in the brain [45].

\section{Materials and Methods}

Ethics approval was obtained from Kafkas University Local Ethics Committee for Animal Experiments (Date: 20/01/2012, Decision No. 02 and Research code: KAU-HADYEK / 2011-45). This study was supported by Kafkas University Scientific Research Project Fund (Project No. 2012-VF-27).

Approximately 10-12 weeks old, 30 male Sprague Dawley rats were used in this study. The rats were divided into 3 groups. Melatonin was administered daily for 3 weeks intraperitoneally at a dose of $10 \mathrm{mg} / \mathrm{kg}$, the most commonly applied in studies [46,47]. $10 \mathrm{mg} /$ $\mathrm{kg}$ of melatonin (Sigma-M5250), which was dissolved in ethanol $(8 \mathrm{mg} / \mathrm{ml}$ ) and diluted with saline, was intraperitoneally injected daily for 21 days to rats in the treatment group. The same amount of ethanol and saline were administered intraperitoneally to the sham group daily for 21 days. The control group received nothing.

Following body weight measurements at the end of three-week (21 days) of study period, liver and kidney tissue samples of rats were collected by euthanasia via cervical dislocation under ether anesthesia. Tissue samples collected for histological examination were embedded in paraffin following routine histological processing.

Sections $(5 \mu \mathrm{m})$ from the paraffin blocks were stained with Crossman's triple staining, Hematoxylin and eosin (H\&E) [48].

Stereo Investigator software was used for the histometric examinations. Among the groups, the 40x objective was used to count binucleated hepatocytes in the same region of the liver tissue. A counting area was determined to be $3025 \mu \mathrm{m}^{2}$ and 50 counting areas were selected at random for each rat (Total $151250 \mu \mathrm{m}^{2}$ areas for each rat). The data obtained by the counting of binucleated hepatocytes were evaluated statistically. 
Avidin-Biotin-Peroxidase Complex (ABC) technique was used to investigate IGF-I and ghrelin immunoreactivity in the liver and kidney tissue [49]. Following deparaffinization and rehydration, sections were rinsed with PBS (Phosphate Buffer Solution) and incubated in $3 \% \mathrm{H}_{2} \mathrm{O}_{2}$ (prepared in $0.1 \mathrm{M} \mathrm{PBS}$ ) for $15 \mathrm{~min}$ in order to block the endogenous peroxidase activity. After rinsing with PBS, sections were put in citrate buffer solution ( $\mathrm{pH}$ 6.0) and then processed in the microwave oven for 10 minutes in order to expose the antigenic sites. After rinsing with PBS again, sections were incubated in appropriate (Ultra V Block, Invitrogen, HistostainPlus Bulk Kit-85-9043) serum (10\%) 10 minutes. Following being rinsed with PBS, sections were incubated in anti IGF-I antibody (Bioss bs-0014R) (liver 1:50 and kidney 1: 125 dilution ratio) for 1 hour and in anti-Ghrelin antibody (Phonex H-031-31) (liver 1:1000 and kidney 1: 400 dilution ratio) for overnight at room temperature. After being rinsed with PBS, biotinylated secondary antibody (Ultravision Detection system Anti-Rabbit, Biontinylated Goat Anti-Rabbit, Invitrogen, Histostain-Plus Bulk Kit-859043) was applied to sections and sections were kept at room temperature for 30 minutes. After rinsing with PBS, sections were kept at room temperature for 30 minutes with added streptavidin-horseradish peroxidase (Invitrogen, Histostain-Plus Bulk Kit-859043). Sections were rinsed again with PBS and DAB (Thermo Scientific) was used for chromogen application. H\&E staining was used for counter-staining. Preparations were examined under BX-051 Olympus (JAPAN) research microscope and photographed.

IGF-I and ghrelin immunoreactivity in tissues was graded from 0 to +3 (0: no reaction; 1 : minimal reaction, 2 : moderate reaction; 3: strong reaction) according to intensity and extent of staining.

In order to determine whether immunoreactivities in tissues are specific for IGF-I and ghrelin, negative control was performed with same procedures, except the addition of primary antibody.

The binucleated hepatocytes in the same area of the liver were counted by using a computer program called Stereo Investigator. Following hepatocyte counting, statistical analysis was performed and evaluated.

Statistical Package for the Social Sciences (SPSS) version 2.0 was used for statistical analysis [50]. One-way analysis of variance (ANOVA) test was used to determine differences between groups and Duncan's new multiple range test (MRT), a multiple comparison procedure, was used to determine the source of the difference between multiple groups.

\section{Results}

Statistically significant $(\mathrm{p}<0.05)$ difference was determined between control and treatment groups regarding mean body weight values. Although there was a difference between sham and treatment groups, it was not statistically significant. Melatonin administration was found to increase body weight (Table 1).

\begin{tabular}{|c|c|c|c|c|}
\hline Day & Group & Mean Body Weight (gr) & SD & F \\
\hline \multirow{3}{*}{ Day 1 } & Treatment & $288.7^{\mathrm{a}}$ & 27.0 & \multirow{3}{*}{0.38} \\
\cline { 2 - 4 } & Sham & $284.5^{\mathrm{a}}$ & 47.4 & \\
\cline { 2 - 4 } & Control & $298.1^{\mathrm{a}}$ & 29.4 & \\
\hline \multirow{3}{*}{ Day 21 } & Treatment & $248.0^{\mathrm{a}}$ & 40.4 & \multirow{3}{*}{$14.20^{*}$} \\
\cline { 2 - 4 } & Sham & $257.6^{\mathrm{a}}$ & 30.9 & \\
\cline { 2 - 4 } & Control & $321.4^{\mathrm{b}}$ & 27.9 & \\
\hline
\end{tabular}

SD: Standard Deviation

F: F value, ${ }^{*} \mathrm{p}<0.05$

Table 1: Comparison of daily mean body weights between the groups

No statistically significant difference was found between control and sham groups in terms of number of binucleated hepatocytes in the liver. A statistically significant $(\mathrm{p}<0.05)$ increase was determined in the treatment group compared to control and sham groups (Table 2) (Figure 1a).
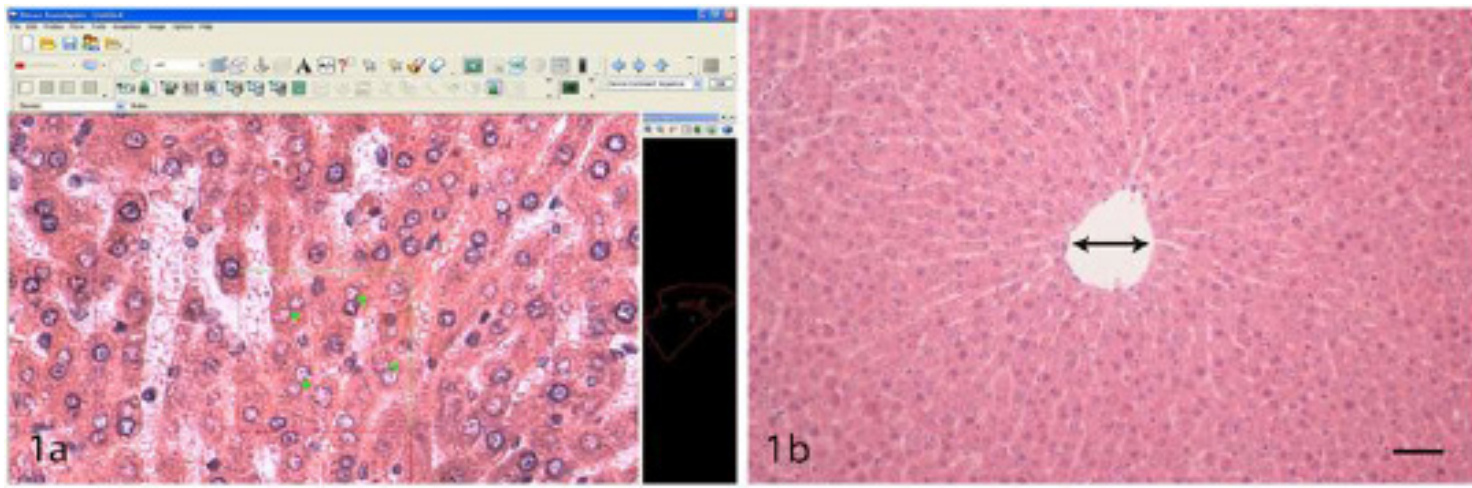

Figure 1: (a) The demonstration of binucleated hepatocyte count on the program; (b) Liver tissues in

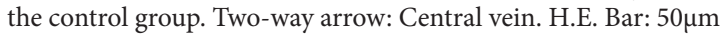




\begin{tabular}{|c|c|c|c|c|}
\hline Groups & $\mathbf{n}$ & $\begin{array}{l}\text { The Number of Binucleated Hepatocytes } \\
\text { (The value of a count area: } 3025 \mu \mathrm{m}^{2} \text { ) }\end{array}$ & SD & F \\
\hline Treatment & 10 & $0.19^{\mathrm{a}}$ & 0.45 & \multirow{3}{*}{$7.635^{\star}$} \\
\hline Sham & 10 & $0.13^{b}$ & 0.37 & \\
\hline Control & 10 & $0.10^{\mathrm{b}}$ & 0.31 & \\
\hline
\end{tabular}

SD: Standard Deviation

F: F value, ${ }^{*} \mathrm{p}<0.05$

Table 2: Comparison of number of binucleated hepatocytes between the groups

There were no differences between all groups in terms of histological examination findings in the liver (Figure 1b) and kidney tissues.

IGF-I immunoreactivity was observed to be only cytoplasmic in hepatocytes in all groups. Cytoplasmic immunoreactivity was observed only in the bile ducts in the trias hepatica (Figure 2a). Strong immunoreactivity was identified especially in hepatocytes in the interlobular connective tissue and around the central veins. There was no difference between sham and control groups regarding IGF-I immunoreactivity. Differences were detected between the treatment group and the other two groups. Although IGF-I immunoreactivity was strong and clustered in hepatocytes around central veins and interlobular connective tissue in control and sham groups the immunoreactivity in hepatocytes in the treatment group was found to be strong and widespread across the tissue (Figure $2 \mathrm{~b}$ and $\mathrm{c}$ ) (Table 3 ).
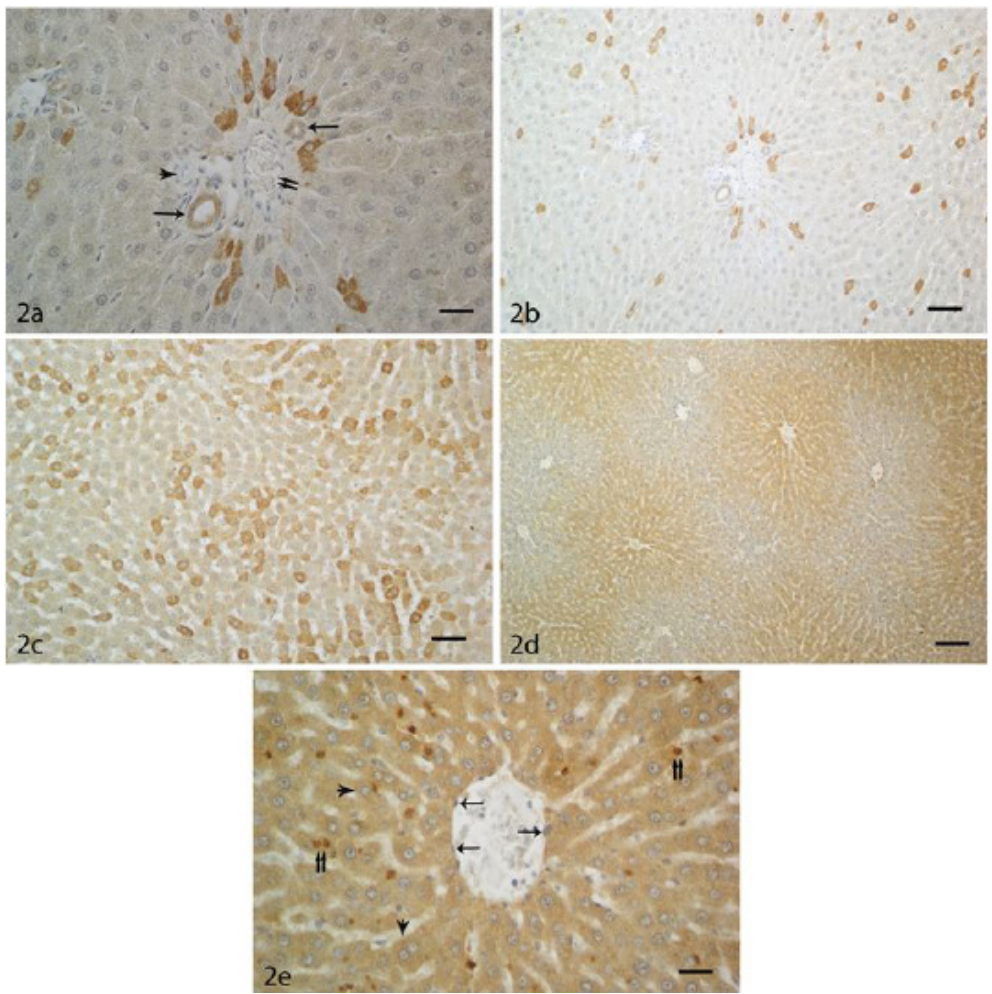

Figure 2: (a) IGF-I immunoreactivity in the liver in the control group. Arrows: Bile ducts, Double arrows: Interlobular vein, Arrowhead: Hepatic artery. Bar: $25 \mu \mathrm{m}$; (b) Clustered IGF-I immunoreactivity in the liver tissue of the control group. Bar: $50 \mu \mathrm{m}$; (c) Widespread IGF-I immunoreactivity in the liver tissue of the treatment group. Bar: $50 \mu \mathrm{m}$; (d) Ghrelin immunoreactivity in the liver tissue in the treatment group. Bar: $100 \mu \mathrm{m}$; (e) Ghrelin immunoreactivity in the liver tissue of the treatment group. Arrows: Endothelial cell, Arrowhead: Hepatocytes, Double arrows: Structures showing immunoreactivity in the cytoplasm of hepatocytes. Bar: $25 \mu \mathrm{m}$

\begin{tabular}{|c|c|c|c|c|c|c|}
\hline \multirow[b]{3}{*}{ Structures in the Liver } & \multicolumn{6}{|c|}{ Reaction Intensity } \\
\hline & \multicolumn{3}{|c|}{ IGF-I } & \multicolumn{3}{|c|}{ Ghrelin } \\
\hline & $\begin{array}{l}\text { Control } \\
\text { Group }\end{array}$ & $\begin{array}{l}\text { Sham } \\
\text { Group }\end{array}$ & $\begin{array}{l}\text { Treatment } \\
\text { Group }\end{array}$ & $\begin{array}{l}\text { Control } \\
\text { Group }\end{array}$ & $\begin{array}{l}\text { Sham } \\
\text { Group }\end{array}$ & $\begin{array}{l}\text { Treatment } \\
\text { Group }\end{array}$ \\
\hline Connective tissue & - & - & - & +2 & +2 & +2 \\
\hline Interlobular bile duct & +3 & +3 & +3 & +3 & +3 & +3 \\
\hline $\begin{array}{l}\text { Hepatocytes around interlobular } \\
\text { connective tissue }\end{array}$ & +2 & +2 & +3 & +1 & +1 & +1 \\
\hline Hepatocytes around central vein & +2 & +2 & +3 & +2 & +2 & +2 \\
\hline Hepatocytes in other areas & +2 & +2 & +3 & +1 & +1 & +1 \\
\hline
\end{tabular}

Table 3: IGF-I and ghrelin reaction intensity in the structures in the liver 
Cytoplasmic ghrelin immunoreactivity was observed in the hepatocytes. Immunoreactivity was observed only in the bile ducts in the trias hepatica. Ghrelin immunoreactivity was especially strong in a few rows of hepatocytes around central vein, and weaker reaction was observed in other areas (Figure 2d). Scattered reactions were observed also in some connective tissue areas. These results were similar in all groups. In all three groups, intense reactivity was also determined in some local areas in the cytoplasm of hepatocytes. These immunoreactivity-showing structures were found to be localized to certain areas of the tissue (Figure 2e).

IGF-I immunoreactivity was not observed in glomeruli, descending limb of loop of Henle, vascular endothelium and connective tissue. Very strong immunoreactivity was observed in the proximal tubules, distal tubules and ascending limb of loop of Henle (Figure $3 \mathrm{a}$ and $\mathrm{b}$ ). Also IGF-I immunoreactivity was observed in the collecting ducts and papillary ducts, and the intensity of immunoreactivity was observed to increase from collecting ducts towards papillary ducts. These findings were similar in all three groups. Individual cells exhibiting intense IGF-I immunoreactivity were determined among the epithelial cells that formed collecting ducts also in all groups (Figure 3c).

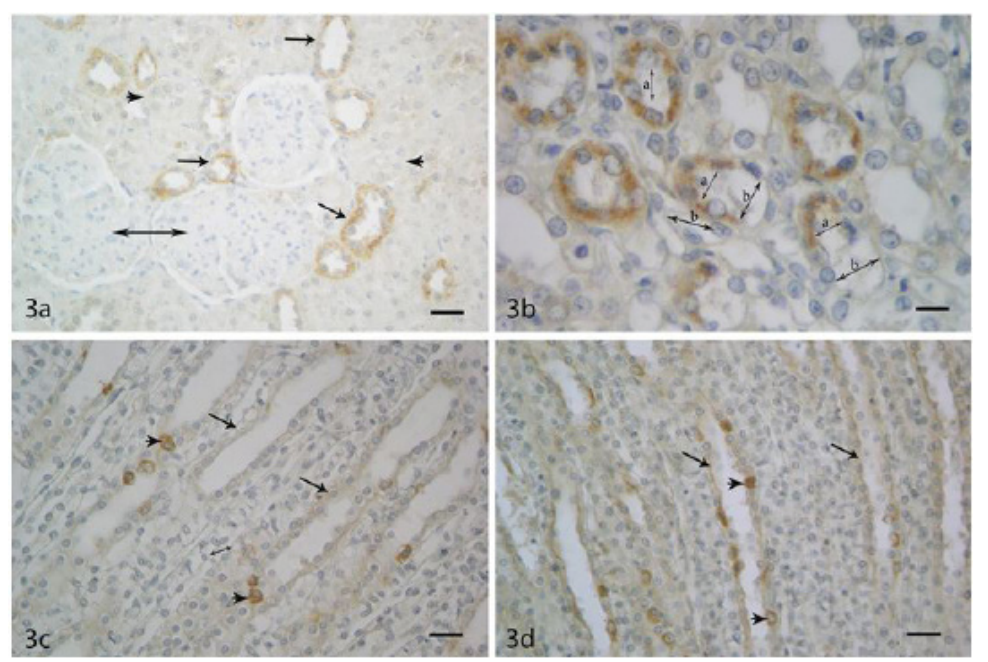

Figure 3: (a) IGF-I immunoreactivity in the kidney tissue in the control group. Arrows: Distal tubules, Arrowhead: Proximal tubules, Two-way arrow: Glomeruli. Bar: $25 \mu \mathrm{m}$; (b) IGF-I immunoreactivity in the kidney tissue in the treatment group. a: Ascending limb of loop of Henle, b: Descending limb of loop of Henle. Bar: $10 \mu \mathrm{m}$; (c) IGF-I immunoreactivity in the kidney in the control group. Arrows: Collecting tubules, Arrowhead: Individual cells showing intense cytoplasmic immunoreactivity, Two-way arrow: Descending limb of loop of Henle. Bar: $25 \mu \mathrm{m}$; (d) IGF-I immunoreactivity in the collecting tubules in the treatment group. Arrows: Collecting tubules, Arrowhead: Individual cells showing intense immunoreactivity. Bar: $25 \mu \mathrm{m}$

No difference was observed between control and sham groups in terms of IGF-I immunoreactivity. Despite weak reaction in the control and sham groups, proximal tubules demonstrated a more intense reaction in the treatment group (Figure 3a). IGF-I immunoreactivity in the collecting ducts was more intense in the treatment group than the other groups (Figure $3 \mathrm{~d}$ ).

Although cytoplasmic ghrelin immunoreactivity was observed in the proximal and distal tubules, no reaction was observed in glomeruli (Figure 4a). While ghrelin immunoreactivity was determined in the descending limb of loop of Henle in control and sham groups, it was not observed in the treatment group (Figure $4 \mathrm{~b}$ and c). Very strong ghrelin immunoreactivity was observed

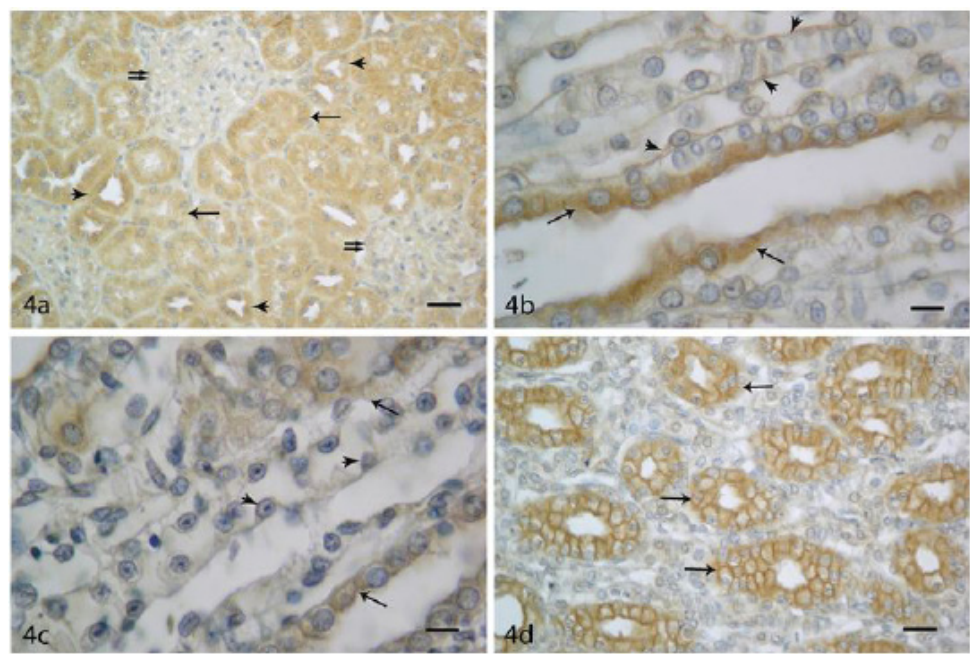

Figure 4: (a) Ghrelin immunoreactivity in the kidney tissue in the control group. Arrows: Proximal tubules, Arrowhead: Distal tubules, Double arrows: Glomerulus. Bar: $25 \mu \mathrm{m}$; (b) Ghrelin immunoreactivity in the medulla of kidney tissue in the control group. Arrows: Collecting tubules, Arrowhead: Descending limb of loop of Henle. Bar: $10 \mu m$; (c) Ghrelin immunoreactivity in the medulla of kidney tissue in the treatment group. Arrows: Collecting tubules, Arrowhead: Descending limb of loop of Henle. Bar: $10 \mu \mathrm{m}$; (d) Intense ghrelin immunoreactivity in the renal papillary duct in the sham group. Arrows: Papillary duct. Bar: $25 \mu \mathrm{m}$ 
in the ascending limb of loop of Henle in all groups. Ghrelin immunoreactivity was observed in collecting tubules and papillary ducts in all groups, and this immunoreactivity was determined to increase from collecting ducts towards the papillary ducts. Immunoreactivities in collecting tubules and papillary ducts were determined to be weaker in the treatment group compared to other groups (Figure $4 \mathrm{~b}, \mathrm{c}$ and d).

No immunoreactivity was detected in negative controls that were conducted to determine whether ghrelin and IGF-I immunoreactivity in the liver and kidney were specific or not (Figure $5 \mathrm{a}$ and $\mathrm{b}$ ).
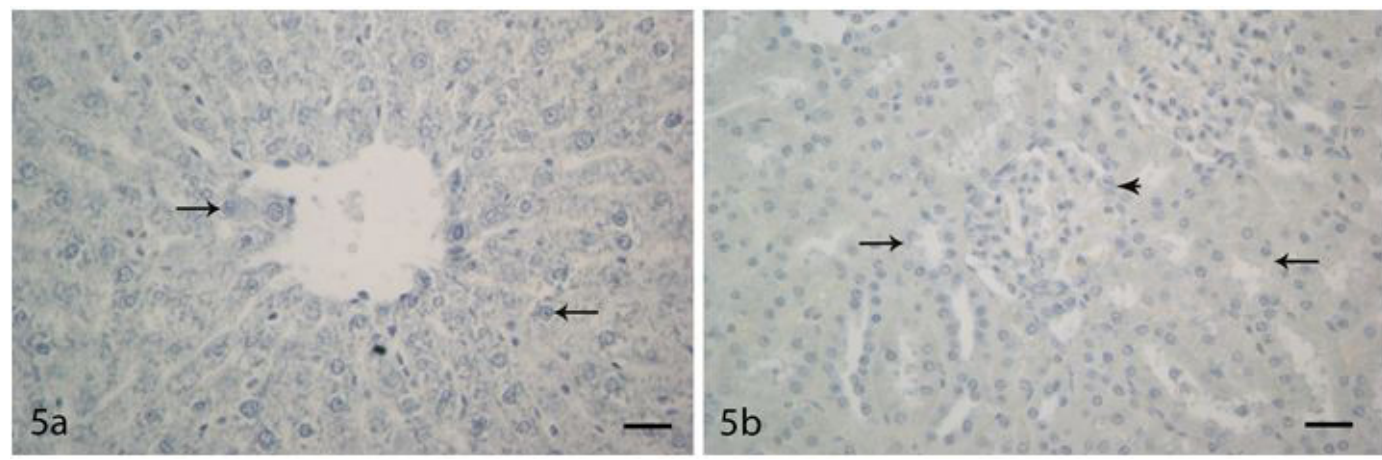

Figure 5: (a) Negative IGF-I immunoreactivity in the liver tissue in the treatment group (Negative control). Arrows: Hepatocytes. Bar: $25 \mu \mathrm{m}$; (b) Negative ghrelin immunoreactivity in the kidney tissue in the control group (Negative control). Arrows: Renal tubules, Arrowhead: Glomerulus. Bar: $25 \mu \mathrm{m}$

IGF-I and ghrelin reaction intensities in the liver and kidney tissues are shown in Table 3 and 4.

\begin{tabular}{|c|c|c|c|c|c|c|}
\hline & \multicolumn{5}{|c|}{ Reaction Intensity } \\
\hline & \multicolumn{3}{|c|}{ IGF-I } & \multicolumn{3}{c|}{ Ghrelin } \\
\hline Structures in the Kidney & $\begin{array}{c}\text { Control } \\
\text { Group }\end{array}$ & $\begin{array}{c}\text { Sham } \\
\text { Group }\end{array}$ & $\begin{array}{c}\text { Treatment } \\
\text { Group }\end{array}$ & $\begin{array}{c}\text { Control } \\
\text { Group }\end{array}$ & $\begin{array}{c}\text { Sham } \\
\text { Group }\end{array}$ & $\begin{array}{c}\text { Treatment } \\
\text { Group }\end{array}$ \\
\hline $\begin{array}{c}\text { Proximal tubules } \\
\text { Descending limb of loop of } \\
\text { Henle }\end{array}$ & -2 & +2 & +3 & +2 & +2 & +2 \\
\hline Ascending limb of loop of Henle & +3 & - & - & +1 & +1 & - \\
\hline Distal tubules & +3 & +3 & +3 & +3 & +3 & +3 \\
\hline Collecting tubules & +1 & +1 & +2 & +3 & +3 & +1 \\
\hline Papillary duct & +2 & +2 & +2 & +3 & +3 & +1 \\
\hline
\end{tabular}

Table 4: IGF-I and ghrelin reaction intensity in the structures in the kidney

\section{Discussion}

In this study, the effects of exogenous administration of melatonin on the immunohistochemical localization of ghrelin and IGF-I in liver and kidney of rats were examined.

It was reported that melatonin administration led to reduce in live weight [44,51]. In our study, melatonin administration also reduced live weight.

Wessam et al. [52] studied to determine protective effects of melatonin on toxicity and oxidative stress in rat liver and they reported that melatonin-treated rats showed no histologic changes and liver had with normal histological appearance.

Ergin et al. [53] investigated the effects of chronic melatonin administration on renin granules in rat kidney and according to their result no histological differences were observed in the kidney glomerulus and juxtaglomerular apparatus between the control group and the melatonin-treated group.

It was reported that melatonin administration did not cause histological changes in the liver [52] and kidney [53]. In the present study, no histological differences were observed between the liver and kidney of the experimental, sham and control groups.

We did not encounter a study about the number of binucleated hepatocytes to discuss. It was informed that melatonin suppressed apoptosis in normal cells and induced apoptosis in tumor cells [54]. In another study, it was reported that melatonin had a limited effect on the function of normal cells and did not change metabolic activity [55]. It was notified that melatonin had a healing effect on hepatocytes by reducing necrotic areas in the liver of exogenous melatonin-treated rats with pancreatitis [56]. In a study, melatonin was reported to increase mitotic activity in astrocyte depending on dose [57]. In the present study, it was observed that the application of exogenous melatonin led to increase in the number of binucleated hepatocytes. Melatonin has been reported to affect metabolic activity [55], to increase mitotic activity [57] and to reduce apoptosis in normal cells [54]. We thought that melatonin triggered mitotic activity in hepatocytes then the number of binucleated hepatocytes increased. 


\section{Evaluations of IGF-I and Ghrelin İmmunoreactivity in Liver and Kidney of Control Groups}

IGF-I immunoreactivity in hepatocytes was found to be cytoplasmic in parallel to the literature reports [58,59]. However, Oner et al. [59] reported that there was nuclear reaction. Hansson et al. [58] reported that IGF-I immunoreactivity was seen in ductus biliferus. In our study, IGF-I immunoreactivity was also observed in the ductus biliferus.

Bestetti et al. [60] notified that IGF-I immunoreactivity was stronger in the hepatocytes around the periphery of the vena centralis than in the interstitial hepatocytes. They explained that the cause of this perivascular localization of IGF-I resulted from giving IGF-I to the systemic circulation. In a study [61], it was reported that all hepatocytes contained IGF-I mRNA. However, Bestetti et al. [60] stated that not all hepatocytes show the same IGF-I immunoreactivity at the same level. They thought that it caused the cells that were active in synthesis of IGF-I to show immunoreactivity [60].

Our findings were similar to those of Bestetti et al. [60] in terms of immunoreactivity in hepatocytes, especially strong immunoreactivity around the vena centralis. We thought that immunoreactiviy may be due to the high metabolic activity in these regions because syntesis of IGFs [62,63].

In studies [64,65], it was observed at different levels of ghrelin immunoreactivity in rat hepatocytes. Guo et al. [64] reported that ghrelin immunoreactivity in hepatocytes was detected in the cytoplasm.

Our results about immunohistochemical distribution of ghrelin were parallel to those of Tas et al. [65] and Guo et al. [64]. In addition, the results related to immunohistochemical distribution of ghrelin in our study were cytoplasmic and supported the findings of Guo et al. [64]. In our study, we found that there was the strong immunoreactivity in ductus biliferus and in hepatocytes around the vena centralis and there was no ghrelin immunoreactivity in kupffer and endothelial cells.

Hansson et al. [58] noticed that IGF-I immunoreactivity was seen only descending loop of henle and collecting ducts in the kidney of the rats, and no immunoreactiviy was observed in other structures. Bortz et al. [66] found localized and specific IGF-I immunoreactivity in the cortical and medullary collecting ducts in rat kidney.

In our study, IGF-I immunoreactivity was also determined in collecting tubules (tubulus col-lectivus and ductus papillaris) parallel to the literature reports $[58,66]$. However, our findings were different from those of Hansson et al. [58], which showed that an immunoreactivity was present in the henle's loop, supporting the findings of Bortz et al. [66]. In our study, IGF-I immunoreactiviy was not seen in glomeruli similar to that of the study of Hansson et al. [58] and Bortz et al. [66].

In the present study, the ghrelin was observed in the distal tubules of the kidney like the result of many studies [13,67-69]. Unlike the studies [13,67-69], our study showed that ghrelin immunoreactivity was present in the tubulus proximalis, descending loop of henle and collecting ducts. Aydin et al. [67] detected ghrelin immunoreactivity in proximal tubules like that of our study.

\section{Evaluations of Melatonin Applications}

It is known that melatonin is secreted by pineal gland in the dark and is a strong free radical scavenger and general antioxidant substance [3]. There are studies [40,42] in the mammals that indicate that there is a link between pineal gland function and GHIGF-I axis. It was showed that pinealectomy and long-term melatonin administration changed the synthesis and release of GH and IGF-I, as well as the tyroid, adrenal cortex, and testicular hormones [40].

Vriend et al. [42] noticed that GH-IGF-I concentrations significantly increased after melatonin injection to Syrian male hamsters in evening for 10 weeks. They thought that this increase in IGF-I concentrations might be due to the effect of exogenous melatonin injection on IGF-I production by triggering changes in GH concentrations.

Pawlikowski et al. [70] reported that melatonin induces a significant increase in serum levels of IGF-I by stimulating IGF-I release. Ostrowska et al. [40] showed that melatonin had effects on IGF-I synthesis and secretion by triggering directly or indirectly stimulates changes in concentrations of other hormones and growth factors. They also reported that the pineal gland affected the GH-IGF-I function during the day and play an important role in the IGF-I mechanism depending on changes in the concentrations of endogenous melatonin.

Picinato et al. [41] reported that melatonin modulated the growth and differentiation of pancreatic islets by activating IGF-I and insulin receptor signalling pathways.

Oner et al. [59] notified that melatonin administration increased IGF-I immunoreactivity in the hepatocytes.

In our study, we observed that IGF-I immunoreactivity between control and sham groups in the liver was similar to each other in terms of area and concentration. In the melatonin-treated rats, IGF-I immunoreactivity was detected in almost all part of the liver. We thought that melatonin triggered IGF-I release in all hepatocytes. IGF-I immunoreactivity was weak in the tubulus proximalis and collective ducts in the kidney of the control and sham groups, while strong reactivity was detected in those of the experimental group. We concluded that melatonin administration increased IGF-I immunoreactivity, especially in the liver and kidney. In some studies [40-42,70], it was reported that melatonin increased serum levels of IGF-I, and another study [59] reported that it also increased IGF-I immunoreactivity in hepatocytes. 
Canpolat et al. [44] reported that the amount of ghrelin in the hypothalamic nucleus was reduced by pinealectomized and increased by melatonin administration. Mustonen et al. [45] notified that melatonin administration decreased ghrelin levels in circulation by suppressing ghrelin production.

We observed that melatonin administration did not change ghrelin immunoreactivity in the liver. There was little change in ghrelin immunoreactivity in the kidney of melatonin group. Melatonin was found to reduce ghrelin immunoreactivity in collective ducts and ductus papillaris. While ghrelin reactivity was not observed in descending loop of henle in melatonin-treated group, reaction was observed in that of other groups. We identified the reduction in ghrelin immunoreactivity and it was similar to results of study [45]. In the study [45], it was determined that ghrelin decrease at the serum level. We thought that the melatonin administration had an different effect on each organ. Studies [44,45] supported our findings.

\section{Conclusion}

In conclusion, it was observed that ghrelin and IGF-I immunohistochemically localized at the same area in both liver and kidney of all groups. These findings show clearly the relationship between ghrelin and IGF-I. Melatonin administration decreases live weight and induces mitotic activity in the liver (binucleated hepatocytes), and increases IGF-I immunoreactivity in the liver and kidney, and decreased ghrelin immunoreactivity in the kidney but not in the liver. We thought that melatonin causes an increase in IGF-I immunoreactivity in the liver and kidney via suppression of ghrelin release. However, new studies are needed to make clarified the relationship between melatonin, ghrelin and IGF-I.

\section{References}

1. Brzezinski A (1997) Melatonin In humans. N Engl J Med 336: 186-95.

2. Junqueira LC, Carneiro J, Kelley RO (1993) Temel Histoloji ( $7^{\text {th }}$ Edn) Çev. Ed, Barış Kitabevi, İstanbul, Turkey.

3. Yazıcı C, Köse K (2004) Melatonin: Karanlığın antioksidan gücü. Erciyes Üniv Sağ Bil Derg 13: 56-65.

4. Hardeland R, Reiter RJ, Poeggeler B, Tan DX (1993) The significance of the metabolism of the neurohormone melatonin: antioxidative protection and formation of bioactive substances. Neurosci Biobehav Rev 17: 347-57.

5. Ianaş O, Olinescu R, Bádescu I (1991) Melatonin involvement in oxidative processes. Endocrinologie 29: 147-53.

6. Koral Taşçı S, Deprem T, Bingöl SA, Eliş Yıldız S, Aslan Ş (2016) Effects of melatonin on catalase enzyme in mouse kidney tissue. Kafkas Univ Vet Fak Derg 22(6): 917-22.

7. Reiter RJ (1996) Functional aspects of the pineal hormone melatonin in combating cell and tissue damage induced by free radicals. Eur J Endocrinol 134: 412-20.

8. Arendt J (1988) Melatonin. Clin Endocrinol 29: 205-29.

9. Reiter RJ (1993) Interactions of the pineal hormone melatonin with oxygen- centered free radicals: a brief review. Braz J Med Biol Res 26: $1141-55$.

10. Korbonits M, Goldstone AP, Gueorguiev M, Grossman AB (2004) Ghrelin-a hormone with multiple functions. Front Neuroendocrinol 25: 27-68.

11. Kojima M, Hosoda H, Matsuo H, Kangawa K (2001) Ghrelin: discovery of the natural endogenous ligand for the growth hormone secretagogue receptor. Trends Endocrinol Metab 12: 118-22.

12. Wang G, Lee HM, Englander E, Greeley GH Jr (2002) Ghrelin not just another stomach hormone. Regul Pept 105: 75-81.

13. Yabuki A, Taharaguchi S, Ichii O, Kojima M, Nishi Y, Mifune H, et al. (2006) Immunohistochemical localization of ghrelin in rodent kidneys. Histochem Cell Biol 126: 231-8.

14. Cassonı P, Papottı M, Ghe C, Catapano F, Sapıno A, et al. (2001) Identification, characterization, and biological activity of specific receptors for natural (ghrelin) and synthetic growth hormone secretagogues and analogs in human breast carcinomas and cell lines. J Clin Endocrinol Metab 86: $1738-45$.

15. Dornonville de la Cour C, Lindström E, Norlén P, Håkanson R (2004) Ghrelin stimulates gastric emptying but is without effect on acid secretion and gastric endocrine cells. Regul Pept 120: 23-32.

16. Gnanapavan S, Kola B, Bustin SA, Morris DG, Mcgee P, et al. (2002) The tissue distribution of the mRNA of ghrelin and subtypes of its receptor, GHS-R, in humans. J Clin Endocrinol Metab 87: 2988-91.

17. Hataya Y, Akamızu T, Takaya K, Kanamoto N, Ariyasu H, et al. (2001) A low dose of ghrelin stimulates growth hormone (GH) release synergistically with GHreleasing hormone in humans. J Clin Endocrinol Metab 86: 552-5.

18. Morton GJ, Schwartz MW (2001) The NPY/AgRP neuron and energy homeostasis. Int J Obes Relat Metab Disord 25: S56-62.

19. Chung H, Kim E, Lee DH, Seo S, Ju S, et al. (2007) Ghrelin inhibits apoptosis in hypothalamic neuronal cells during oxygen-glucose deprivation. Endocrinology 148(1): 148-59.

20. Takeda R, Nishimatsu H, Suzuki E, Satonaka H, Nagata D, et al. (2006) Ghrelin improves renal function in mice with ischemic acute renal failure. J Am Soc Nephrol 17: 113-21.

21. Kasimay O, Iseri SO, Barlas A, Bangir D, Yegen C, et al. (2006) Grelin ameliorates pancreaticobiliary inflammation and associated remote organ injury in rats. Hepatol Res 36: 11-9.

22. Arvat E, Di Vito L, Broglio F, Papotti M, Muccioli G, et al. (2000) Preliminary evidence that grelin, the natural GH secretagogue (GHS)-receptor ligand, strongly stimulates GH secretion in humans. J Endocrinol Invest 23: 493-5.

23. Kojima M, Hosoda H, Date Y, Nakazato M, Matsuo H, et al. (1999) Ghrelin is a growth-hormone-releasing acylated peptide from stomach. Nature 402: 656-60. 24. Peino R, Baldelli R, Rodriguez-Garcia J, Rodriguez-Segade S, Kojima M, et al. (2000) Grelin-induced growth hormone secretion in humans. Eur J Endocrinol 143: 11-4.

25. Kaiya H, Darras VM, Kangawa K (2007) Grelin in birds: Its structure, distribution and function. J Poult Sci $44: 18$.

26. Li WG, Gavrila D, Liu X, Wang L, Gunnlaugsson S, et al. (2004) Ghrelin inhibits proinflammatory responses and nuclear factor-kappaB activation in human endothelial cells. Circulation 109: 2221-6. 
27. Allan GJ, Flint DJ, Patel K (2001) Insulin-like growth factor axis during embryonic development. Reproduction 122: 31-9.

28. Brook CGD, Dattani M (1989) Somatomedins / insulin-like growth factors In: Clinical Paediatric Endocrinology ( ${ }^{\text {nd }}$ Edn) Blackwell Scientific Publications, Oxford.

29. Guyton AC, Hall JE (1996) Tibbi Fizyoloji (Medical Physiology). Nobel Tibkitabevleri Ltd, Istanbul, Turkey.

30. Norstedt G, Levinovitz A, Moller C, Erikson LC, Anderson G (1988) Expression of insulin-like growth factor I and II mRNA during hepatic development, proliferation and carcinogenesis in the rat. Carcinogenesis 9: 209-13.

31. Fant M, Munro H, Moses AC (1986) An Autocrine / paracrine role for insulin like growth factor in the regulation of human placental growth. J Clin Endocrinol Metab 63: 499-505.

32. Mills NC, D’Ercole AJ, Underwood LE, IIan J (1986) Synthesis of somatomedin C/ insulin-like growth factor 1 bay human placenta. Mol Biol Rep 11: 231-6.

33. Greenspen FS (1991) Somatomedins In: Basic and Clinical Endocrinology, Spencer (Ed) Appleton \& Lange, USA.

34. Burgi U, Gerber H, Peter HJ, Kämpf J, Lemarchand-Beraud T (1994) Transformation of normal thyroid into colloidal goiter in rats and mice. Endocrinol 135: 2688-99.

35. Peter HJ, Burgi U, Gerber H (1996) Pathogenesis of nontoxic diffuse and nodular goiter In: The thyroid (7th Edn) Brawerman LE, Utiger RD, New York Lippincott-Raven, USA.

36. Garcia-Fernandez M, Castilla-Cortazar I, Diaz-Sanchez M, Navaro I, Puche JE, et al. (2005) Antioxidant effects of insulin-like growth factor-1(IGF-I) in rats with advanced liver cirrhosis. BMC Gastroenterol 5: 5-7.

37. Baker J, Liu JP, Robertson EJ, Efstratiadis A (1993) Role of insulin-like growth factors in embriyonic and postnatal growth. Cell 75: 73-82.

38. LeRoith D (1997) Insulin-like growth factors. N Engl J Med 336: 633-40.

39. Whatmore AJ, Hall CM, Jones J, Westwood M, Clayton PE (2003) Ghrelin concentrations in healthy children and adolescents. Clin Endocrinol 59: 649-54.

40. Ostrowska Z, Kos-Kudla B, Swietochowska E, Marek B, Kajdaniuk D, et al. (2001) Influence of pinealectomy and long-term melatonin administration on GHIGF-I axis function in male rats. Neuro Endocrinol Lett 22: 255-62.

41. Picinato MC, Hirata AE, Cipolla-Neto J, Curi R, Carvalho CR, et al. (2008) Activation of insulin and IGF-I signaling pathways by melatonin through MT1 receptor in isolated rat pancreatic islets. J Pineal Res 44: 88-94.

42. Vriend J, Sheppard MS, Borer KT (1990) Melatonin increases serum growth hormone and insülin-like growth factor I (IGF-I) leves in male Syrian hamsters via hypothalamic neurotransmitters. Growth Dev Aging 54: 165-71.

43. Oner J, Oner H, Sahin Z, Demir R, Ustunel I (2008) Melatonin is as effective as testesterone in the prevention of solves muscle atropy induced by castration in rats. Anat Rec 291: 448-55.

44. Canpolat S, Aydın M, Yaşar A, Çolakoğlu N, Yılmaz B, et al. (2006) Effects of pinealectomy and exogenous melatonin on immunohistochemical ghrelin staining of arcuate nucleus and serum ghrelin leves in the rat. Neurosci Lett 410: 132-6.

45. Mustonen AM, Nieminen P, Hyvarinen H (2001) Preliminary evidence thatpharmacologic melatonin treatment decreases rat ghrelin levels. Endocrine 16: 43-6. 46. Koral Taşçı S, Gülmez N (2014) Immunohistochemical distribution of glutathione peroxidase and its gene expression via RT-PCR in the liver tissue of melatoninadministered mice [Melatonin uygulanan farelerin karaciğer dokusunda glutatyon peroksidazın immunohistokimyasal dağıllmı ve RT PCR ile gen expresyonu]. Turk J Vet Anim Sci 38: 145-50.

47. Schaffazick SR, Siqueira IR, Badejo AS, Jornada DS, Pohlmann AR, et al. (2008) Incorporation In polymeric nanocapsules Improves the antloxldant effect of melatonin against lipid peroxidation In mice brain and liver. Eur J Pharm Blopharm 69: 64-71.

48. Luna LG (1968) Manual of histologic staining methods of the Armed Forces Institute of Pathology ( $3^{\text {rd }}$ Edn) New York: McGraw-Hill Book, USA.

49. Hsu SM, Raine L, Fanger H (1981) Use of Avidin-Biotin-Peroxidase Complex (ABC) in immunoperoxidase techniques: a comparison between ABC and unlabeled antibody (PAP) procedures. J Histochem Cytochem 29: 577-80.

50. SPSS (2010) 2.0 Windows and Smart Viewer.

51. Ríos-Lugo MJ, Cano P, Jiménez-Ortega V, Fernández-Mateos MP, Scacchi PA, et al. (2010) Melatonin effect on plasma adiponectin, leptin, insulin, glucose, triglycerides and cholesterol in normal and high fat-fed rats. J Pineal Res 49: 342-8.

52. Wessam M, Wahab A (2012) AlCl3-induced toxicity and oxidative stress in liver of male rats: Protection by melatonin. Life Sci J 9: 1173-82.

53. Ergin K, Başaloğlu HK (2008) Kronik melatonin enjeksiyonunun renin granülleri üzerindeki histolojik etkisi. SDÜ Tip Fak Derg 15: 25-28.

54. Pozo D, Delgado M, Fernandez-Santos JM, Calvo JR, Gomariz RP, et al. (1997) Expression of the Mella- melatonin receptor mRNA in T and B subsets of lymphocytes from rat thymus and spleen. Faseb J 11: 466-73.

55. Natarajan M, Reiter RJ, Meltz ML, Herman TS (2001) Effects of melatonin cell growth, metabolic activity and cell cycle disribution. J Pineal Res 31: 228-33.

56. Çöl C, Dinler K, Hasdemir O, Büyükaşı O, Buğdaycı G, et al. (2010) Exogenous melatonin treatment reduces hepatocyte damage in rats with experimental acute pancreatitis. J Hepato Pan Sci 17: 682-7.

57. Paulose JK, Peters JL, Karaganis SP, Cassone VM (2009) Pieal melatonin acts as a circadian zeitgeber and growth factor in chick astrocytes. J Pineal Res 46: 286-94.

58. Hansson HA, Nilsson A, Isgaard J, Billig H, Isaksson O, et al. (1988) Immunohistochemical localization of insülin-like growth factor I in the adult rat. Histochem 89: 403-10.

59. Oner J, Kuş I, Oner H (2009) Melatonin increases the expression of insulin-like growth factor I in rats with carbontetrachlorid- induced hepatic damage. J Anim Vet Adv 8: 2256-61.

60. Bestetti GE, Blum JW, Rossi GL (1992) Immunohistochemistry of hepatic IGF-I in calf, pig and rat. Zentralbl Veterinarmed A 39: 747-51.

61. Van Neste L, Husman B, Moeller C, Andersson G, Norstedt G (1988) Cellular distribution of somatogenic receptors and insülin-like growth factor-I mRNA in the rat liver. J Endocrinol 119: 69-74.

62. Tanyolaç A (1999) Special Histolog, Yorum Press Publication San, Ankara, Turkey [Özel Histoloji. Yorum Basın Yayın San. Ankara].

63. Shimasaki S, Shimonaka M, Zhang HP, Ling N (1991) Identification of five different insulin-like growth factor binding proteins (IGFBPs) from adult rat serum and molecular cloning of a novel IGFBP-5 in rat and human. J Biol Chem 266: 10646-53.

64. Guo ZF, Ren AJ, Zheng X, Qin YW, Cheng F, et al. (2008) Different responses of circulating ghrelin, obestatin levels to fasting, re-feeding and different food compositions, and their local expressions in rats. Peptides 29: 1247-54. 
65. Taş U, Ögetürk M, Meydan S, Irmak Sapmaz H, Dabak DÖ, et al. (2009) Toluen solutulan sıçanların karaciğerinde ghrelin ekspresyonu. FÜ Sağ Bil Tip Derg 23: 151-4.

66. Bortz JD, Rotwein P, Devol D, Bechtel PJ, Hansen VA, et al. (1988) Focal expression of insülin-like growth factor I in rat kidney collecting duct. J Cell Biol 107: 811-9.

67. Aydın S, Şahin İ, Özkan Y, Dağ E, Günay A, et al. (2012) Examination of the tissue ghrelin expression of rats with diet-induced obesity using radioimmunoassay and immunohistochemical methods. Mol Cell Biochem 365: 165-73.

68. Dönder E, Doğan MM, Kuloğlu T, Dabak DÖ, Kocaman N, et al. (2013) The investigation of the effects of enalapril and losartan on ghrelin immunoreaktivity in kidney of streptozotocin-induced diabetic rats. Firat Tip Derg 18: 1-6.

69. Kuloğlu T, Dabak DÖ (2009) Determination of ghrelin immunoreaktivity in kindey tissues of diabetic rats. Ren Fail 31: 562-6.

70. Pawlikowski M, Kolomecka M, Wojtezak A, Karasek M (2002) Effects of six months melatonin treatment on sleep quality an serum concentrations of estradiol, cortisol, dehydroepiandrosterone sulfate and somatomedin C in elderly women. Neuroendocrinol Lett 23: 17-9.

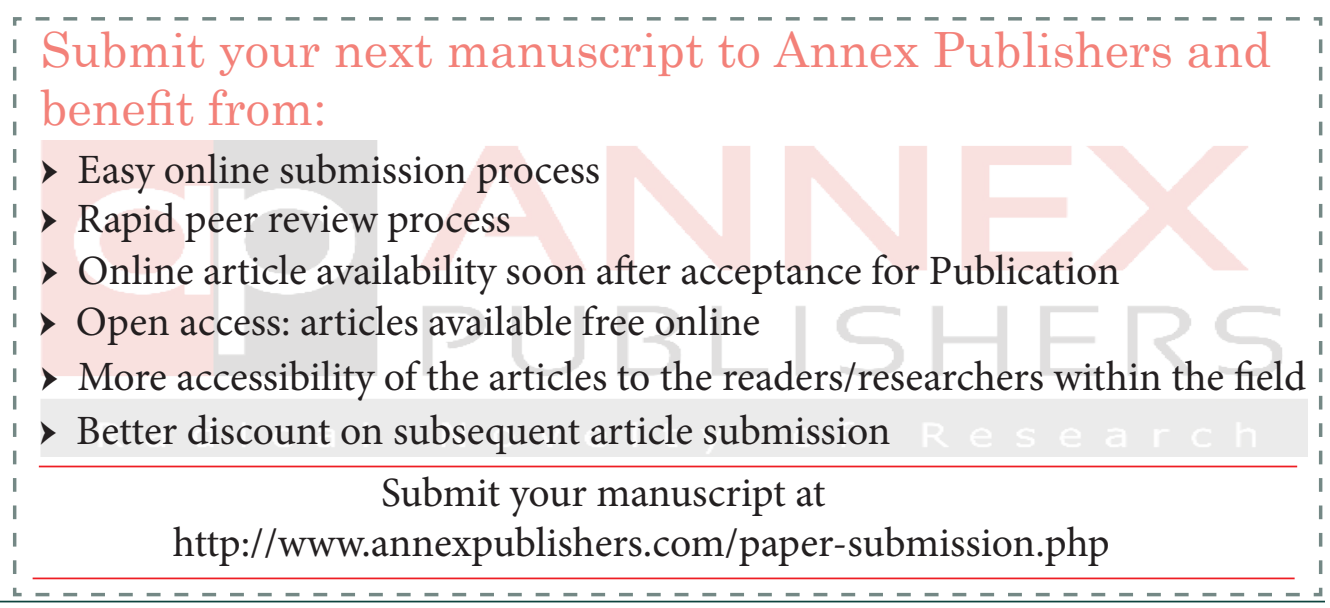

